\title{
Antioxidant capacity of Nitraria retusa leaf extracts against mitomycin C-induced genetic toxicity in male mice
}

\author{
Wagdy K. B. Khalil' ${ }^{*}$, Ekram S. Ahmed, Salwa M. Kassem, Thanaa M. T. Shoman, Mahrousa M. Hassanane and \\ Mariam G. Eshak
}

\begin{abstract}
Background: Recently, a great interest in the usage of new derived drugs extracted from plant has been increased to treat and/or prevent several diseases including cancer. Therefore, the present study was conducted to use Nitraria retusa leaf extract to increase the antioxidant activity and reduce the genotoxic activity of chemotherapeutic drugs mitomycin C (MMC) in male mice. Male Swiss albino mice $(n=80)$ were divided in several experimental groups and treated with single dose of MMC with supplementation of 50 and $100 \mathrm{mg} / \mathrm{kg}$ body wt Nitraria retusa leaf extract for several time intervals (3 days, 1 week, and 1 month).

Results: This study found that MMC-treated mice observed significant increases in the frequency of chromosomal abnormalities in both cell types including bone marrow and spermatocyte cells, induce the mean values of DNA damage, and decrease the expression values of antioxidant enzyme-related genes (CAT, GPx, and GSTT1) compared with control mice. However, supplementation of MMC-treated mice with Nitraria retusa leaf extract suppressed the harmful impacts induced by MMC especially with the high dose and longer duration of the administration.

Conclusion: The results suggested that the protective capacity of the Nitraria retusa leaf extract in protecting the hepatic cells could be attributed to the presence of isorhamnetin 3-o-robinobioside, palmitic acid, and $\beta$-sitosterols in its extract which are known for their anti-tumor and anti-mutagenic activities.
\end{abstract}

Keywords: Nitraria retusa, Mitomycin C, Antioxidants, DNA damage, Mice

\section{Background}

The presence of genotoxic compounds in human surrounding such as the environment, medicaments, and food can affect the DNA structures in the genome and therefore causes several diseases including cancer (De Flora \& Ferguson, 2005; Dong et al., 2015). Mitomycin C (MMC) is an antitumor agent used for chemotherapeutic regime especially for treatment of several types of cancers including anal and colon cancers, bladder cancer, and breast cancer (Gederaas et al., 2014; van Valenberg et al., 2018).

However, there are several side effects of MMC which put it as one of the genotoxicants (Rjiba-Touati et al.,

\footnotetext{
* Correspondence: wagdykh@yahoo.com; wkbassaly@gmail.com Cell Biology Department, National Research Centre, 33 Bohouth st., Dokki, Giza 12622, Egypt
}

2016). MMC is acting as an linking agent for adverse biological action to another in the cell. For the adverse biological action, MMC is associated with apoptosis stimulation, mutagenesis, and suppression of DNA synthesis (Boamah et al., 2007; Mao, Varoglu, \& Sherman, 1999; Zhang, Huang, Cao, Li, \& Xu, 2017).

On the other hand, several detoxification systems play an important role in modulation of the effects of genotoxic substances which are minimizing the DNA damage and mutagenicity (Elmegeed, Khalil, Abdel Raouf, \& Abdelhalim, 2008; Kaur, Kaur, Kumar, \& Kaur, 2014). The pharmaceutical and botanic scientists are extensively searching for the discovery of new natural products having the antioxidant capacity, because it has been reported that a lot of natural products have a high antioxidant capacity and can inhibit oxidative stress 
resulting from many of mutagenic agents inducing DNA damage (Verma \& Gupta, 2015).

Several reports indicated that polyphenolic compounds extracted from natural materials including plants have anti-genotoxic properties (Corona et al., 2017; Surh \& Ferguson, 2003; Williams, Dashwood, Hendricks, \& Bailey, 1989). These reports indicated that the polyphenolic components scavenge free radicals from the cells and consequently protect the cellular systems from oxidative damage. So these protective mechanisms from the natural products are limiting the risk of inducing several degenerative diseases which are associating with the oxidative stress (Barnes, Fouquerel, \& Opresko, 2018). The deficiency in the immune system due to the imbalance between the antioxidant capacity and generation of reactive oxygen species (ROS) is inducing the oxidative damage action. This defect could be attributed from exposure to ROS inducing mutagens or lack of mechanisms of antioxidant defense, or the incidence of drugs associated to the metabolism of ROS such as those used for inflammation and chronic infection treatment (Doleski et al., 2017). On the other hand, if the endogenously formed enzymes and antioxidants associated to enhance the immunity are catalyzed in the metabolism, the ROS amount could be scavenged by supplementation with carotenoids, vitamins, and phenolics existing in vegetables and fruit as exogenous antioxidants (Wolfe \& Liu, 2007).

Nitraria retusa is cultivated widely in North African countries and considered as one of the native perennial plant which belongs to Nitrariaceae family. The leaves of Nitraria retusa in these countries are used as tea, and the extracted flavonoids from Nitraria retusa are known as effective anti-inflammatory natural agents (El-Alali, AlZoui, Gharaibeh, Tawaha, \& Alali, 2012). Moreover, these active ingredients extracted from Nitraria retusa have been recorded for anti-mutagenic and anti-oxidant activities and to enhance apoptosis (Boubaker, Ben Sghaier, Skandrani, Ghedira, \& Chekir-Ghedira, 2012; Boubaker, Skandrani, Bouhlel, et al., 2010).

Therefore, the main objective of the current study was to investigate the protective effects of the Egyptian species of Nitraria retusa against MMC-induced genetic toxicity in male mice.

\section{Methods}

\section{Chemicals}

Mitomycin C (MMC) was purchased from Sigma-Aldrich (Saint Louis, MO 63103, USA). Kits and reagents for cytogenetic and biochemical analyses were purchased from Invitrogen (Germany). Trizol was bought from Invitrogen (Carlsbad, CA, USA). The reverse transcription and PCR kits were obtained from Fermentas (Glen Burnie, MD, USA). SYBR Green Mix was purchased from Stratagene
(La Jolla, CA, USA). All other chemicals and reagents were of analytical grade and obtained from standard commercial suppliers.

\section{Animals}

Eighty adult Swiss albino male mice (21-25 g), purchased from the Animal House Colony, Giza, Egypt, were maintained on standard laboratory diet (protein, 16.04\%; fat, 3.63\%; fiber, $4.1 \%$; and metabolic energy, $0.012 \mathrm{MJ}$ ) and water ad libitum at the Animal House Laboratory, National Research Centre, Dokki, Giza, Egypt. After an acclimation period of 1 week, animals were divided into groups (10 mice/group) and housed individually in filter-top polycarbonate cages, housed in a temperature-controlled $\left(23 \pm 1{ }^{\circ} \mathrm{C}\right)$ and artificially illuminated (12-h dark/light cycle) room free from any source of chemical contamination. All animals received humane care in compliance with the guidelines of the Animal Care and Use Committee of National Research Centre, Egypt (protocol no: 6.1.2004). The proposal of this study had approval from Ethical Committee of National Research Center no: 01.02.2016.

\section{Plant materials}

Nitraria retusa samples were collected from South of Sinai, Egypt (March 2016). This halophyte was identified at Desert Research Center (DRC). A voucher specimen (no. 132, July 2016) was deposited at the Herbarium of the Plants at the DRC.

\section{Plant extracts preparation}

The methods and protocol according to El Hawary, Saad, El Halawany, Ali, and El Bishbishy (2016) have been used with minor modification as following: Fresh leaves of Nitraria retusa were collected during flowering stage in March 2016 from South of Sinai desert. The plant material was washed well with water, dried at room temperature in the dark, and then ground in an electric grinder to give a coarse powder.

About $50 \mathrm{~g}$ of the plant powder was soaked in methanol at room temperature for $24 \mathrm{~h}$. The plant extract was collected dropwise and filtered using Whatman No.1 filter paper. The residues were soaked in methanol and filtered again. Afterwards, the extracted material was then dried, placed in glass vials, and stored frozen at $-20^{\circ} \mathrm{C}$ up to use for biological study.

\section{Experimental design}

Animals were divided into 8 groups (10 animals each) as follow: group 1: control animals treated with physiological saline. Group 2: animals were injected ip with MMC $(1 \mathrm{mg} / \mathrm{kg})$ once daily for 3 days. Groups 3 and 4: animals were injected ip with MMC $(1 \mathrm{mg} / \mathrm{kg})$ once daily for 3 days and combined with oral administration with 
50 or $100 \mathrm{mg} / \mathrm{kg}$ of Nitraria retusa extracts, respectively. Groups 5 and 6: animals were injected ip with MMC (1 $\mathrm{mg} / \mathrm{kg}$ ) once daily for 3 days and combined with oral administration for 1 week with 50 or $100 \mathrm{mg} / \mathrm{kg}$ of Nitraria retusa extracts, respectively. Groups 7 and 8: animals were injected ip with MMC $(1 \mathrm{mg} / \mathrm{kg})$ once daily for 3 days and combined with oral administration for 1 month with 50 or $100 \mathrm{mg} / \mathrm{kg}$ of Nitraria retusa extracts, respectively.

The selected doses of MMC and Nitraria retusa extract were used according to Kalai et al. (2013) and Pawar et al. (2009). Mice were sacrificed $24 \mathrm{~h}$ after treatment termination and subjected to chromosomal aberration analysis in both somatic (bone marrow cells) and germ cells (spermatocyte cells), comet assay, and gene expression of antioxidant enzymes as well as ROS generation.

\section{Chromosomal aberrations analysis}

Cytogenetic analysis was performed on tibia bone marrow cells according to the recommendations of Adler (1974), with slight modifications. Experimental animals were injected (ip) with colchicines $(4 \mathrm{mg} / \mathrm{kg}) 1.5 \mathrm{~h}$ before sacrifice. Both tibia were dissected out and cleaned of any adhering muscle. Bone marrow cells were collected from both tibias by flushing in $\mathrm{KCl}\left(0.075 \mathrm{M}\right.$, at $37^{\circ} \mathrm{C}, 5$ $\mathrm{mL}$ ) and incubated at $37^{\circ} \mathrm{C}$ for $25 \mathrm{~min}$. Materials were centrifuged at $2000 \mathrm{rpm}$ for $10 \mathrm{~min}$, fixed in methanol: acetic acid (Carnoy's fixative, 3:1 v/v). Centrifugation and fixation (in the cold) were repeated five times at least at intervals of $20 \mathrm{~min}$. The material was re-suspended in a little volume of fixative, dropped onto chilled slides, flame-dried and stained in 5\% Sorenson buffered Giemsa (pH 6.8). At least 75 good metaphases containing 42 chromosomes were examined per animal to score different types of aberrations.

For spermatocyte cells, chromosomal preparations were made according to the air-drying method by Evans, Breckon, and Ford (1964). Mice were injected (ip) with colchicines $(0.1 \%) 2 \mathrm{~h}$ before killing by cervical dislocation. The testes were transferred to $2.5 \mathrm{ml}$ of a $2.2 \%$ citrate solution in Petri dishes and the tunica removed. The contents of the tubules were gently teased out with curved forceps. The cell suspension produced was aspirated well and centrifuged at $1000 \mathrm{rpm}$ for $10 \mathrm{~min}$, the supernatant was discarded, and the pellet was re-suspended in $2 \mathrm{ml}$ of hypotonic solution (1\% sodium citrate) at $37^{\circ} \mathrm{C}$. After $12 \mathrm{~min}$, the suspension was centrifuged for $10 \mathrm{~min}$ at $1000 \mathrm{rpm}$. Then, the supernatant was removed. The cells were fixed three times with cold fixative solution (3:1 of methanol and glacial acetic acid). Slides were stained with Giemsa in phosphate buffer $(\mathrm{pH}$ 6.8) for $8 \mathrm{~min}$. Fifty primary spermatocytes/mouse at diakinesis-metaphase I were scored. Abnormalities recorded included univalents ( $\mathrm{x}-\mathrm{y}$ univalent and autosomal univalent), chains, rings, $\mathrm{N} \pm 1$, and polyploidy.

\section{Comet assay}

Peripheral blood lympocytes from male mice were isolated by centrifugation ( $15 \mathrm{~min}, 2000 \mathrm{rpm}$ ) in a density gradient of Gradisol L (Aqua Medica, Lodz, Poland). The concentration of the cells was adjusted to $(1-3) \times$ $10^{5}$ cells/ml by adding RPMI 1640 without glutamine to the single-cell suspension. A freshly prepared suspension of cells in $0.75 \%$ low melting point agarose (Sigma Chemicals) dissolved in phosphate buffer saline (PBS; Sigma Chemicals) was cast onto microscope slides precoated with $0.5 \%$ normal melting agarose. The cells were then lysed for $1 \mathrm{~h}$ at $4{ }^{\circ} \mathrm{C}$ in a buffer consisting of $2.5 \mathrm{M} \mathrm{NaCl}$, 100 mMEDTA, 1\% Triton X-100, $10 \mathrm{mM}$ Tris, $\mathrm{pH} 10$. After the lysis, DNA was allowed to unwind for $40 \mathrm{~min}$ in electrophoretic solution consisting of $300 \mathrm{mM} \mathrm{NaOH}$, $1 \mathrm{mM}$ EDTA, $\mathrm{pH}>13$. Electrophoresis was conducted at $4{ }^{\circ} \mathrm{C}$ for $30 \mathrm{~min}$ at electric field strength $0.73 \mathrm{~V} / \mathrm{cm}(30$ $\mathrm{mA}$ ). The slides were then neutralized with $0.4 \mathrm{M}$ Tris, $\mathrm{pH} 7.5$, stained with $2 \mu \mathrm{g} / \mathrm{ml}$ ethidium bromide (Sigma Chemicals) and covered with coverslips. The slides were examined at $\times 200$ magnification fluorescence microscope (Nikon Tokyo, Japan) to a COHU 4910 video camera (Cohu, Inc., San Diego, CA, USA) equipped with a UV filter block consist of an excitation filter $(359 \mathrm{~nm})$ and barrier filter $(461 \mathrm{~nm})$ and connected to a personal computer-based image analysis system, Lucia-Comet v.4.51. Fifty images were randomly selected from each sample, and the comet tail DNA was measured (Blasiak et al., 2004). Endogenous DNA damage measured as the mean comet tail DNA of peripheral blood lymphocytes of five mice groups (10 mice each). The number of cells scored for each animal was 100 (Blasiak et al., 2004).

\section{Expression of diabetes-related genes}

Isolation of total RNA Total RNA was extracted from the pancreas tissues from treated animals by the standard TRIzol ${ }^{\circ}$ Reagent extraction method (Invitrogen, Germany). The RNA pellet was dissolved in diethylpyrocarbonate (DEPC)-treated water by passing solution a few times through a pipette tip. Total RNA was treated with $1 \mathrm{U}$ of RQ1 RNAse-free DNAse (Invitrogen, Germany) to digest DNA residues, re-suspended in DEPC-treated water. Purity of total RNA was assessed by the $260 / 280 \mathrm{~nm}$ ratio (between 1.8 and 2.1). Additionally, integrity was assured with ethidium bromide-stain analysis of $28 \mathrm{~S}$ and $18 \mathrm{~S}$ bands by formaldehyde-containing agarose gel electrophoresis. Aliquots were used immediately for reverse transcription (Linjawi, Khalil, Hassanane, \& Ahmed, 2015; Salem, Wahba, Eisa, El-Shamarka, \& Khalil, 2017). 
Reverse transcription (RT) reaction The complete Poly $(\mathrm{A})^{+}$RNA isolated from male rat samples was reverse transcribed into cDNA in a total volume of $20 \mu \mathrm{l}$ using RevertAidTM First Strand cDNA Synthesis Kit (MBI Fermentas, Germany). The RT reaction was carried out at $25^{\circ} \mathrm{C}$ for $10 \mathrm{~min}$, followed by $1 \mathrm{~h}$ at $42^{\circ} \mathrm{C}$, and the reaction was stopped by heating for $5 \mathrm{~min}$ at 99 ${ }^{\circ} \mathrm{C}$. Afterwards, the reaction tubes containing RT preparations were flash-cooled in an ice chamber until being used for DNA amplification through quantitative real-time polymerase chain reaction (Khalil, Booles, Hafiz, \& El-Bassyouni, 2018; Sayed, Khalil, Salem, Kenawy, \& El-Sayeh, 2014).

Quantitative real-time polymerase chain reaction (qRT-PCR) PCR reactions were set up in $25 \mu \mathrm{L}$ reaction mixtures containing $12.5 \mu \mathrm{L} 1 \times$ SYBR $^{\circ}$ Premix Ex TaqTM (TaKaRa, Biotech. Co. Ltd., Germany), $0.5 \mu \mathrm{L}$ $0.2 \mu \mathrm{M}$ sense primers, $0.5 \mu \mathrm{L} 0.2 \mu \mathrm{M}$ antisense primer, 6.5- $\mu \mathrm{L}$ distilled water, and $5 \mu \mathrm{L}$ of cDNA template. At the end of each qRT-PCR, a melting curve analysis was performed at $95.0^{\circ} \mathrm{C}$ to check the quality of the used primers. Each experiment included a distilled water control. The quantitative values of RT-PCR (qRT-PCR) of CAT, GPx, and GSTT1 were normalized on the bases of $ß$-actin expression (Table 1). The relative quantification of the target to the reference was determined by using the $2^{-\Delta \Delta C \mathrm{~T}}$ method.

\section{Statistical analysis}

All data were analyzed using the general liner models (GLM) procedure of SAS Institute (1982) followed by the Scheffé test to assess significant differences between groups. The values are expressed as mean \pm SEM. All statements of significant were based on probability of $P<0.05$.

\section{Results}

\section{Effect of Nitraria retusa leaf extract on the chromosomal} aberrations

Induction of chromosomal aberrations in bone marrow cells and spermatocytes are summarized in Tables 2 and 3. The results showed that treatment of male mice with single dose of mitomycin $C$ induced high main values of chromosomal aberrations either in bone marrow cells or spermatocytes compared with control and other treated groups. The aberrations in the types as gap, break, and fragments were observed as the main types of chromosomal aberrations in bone marrow cells exposed to MMC. Additionally, X-Y univalents and chain were the main types of chromosomal abnormalities in spermatocyte cells exposed to MMC. However, MMC-treated mice supplemented with 50 and $100 \mathrm{mg} / \mathrm{kg}$ body wt of Nitraria retusa leaf extracts for 3 days showed decrease in the chromosomal aberrations compared with the male mice treated with $\mathrm{MMC}$ alone but without significant differences. Moreover, MMC-treated mice administrated with 50 and $100 \mathrm{mg} / \mathrm{kg}$ body wt of Nitraria retusa leaf extracts for 1 week and 1 month showed significant decreases $(P<0.05$ and $P<0.01$, respectively) in the chromosomal aberrations compared with the male mice treated with MMC alone.

\section{Effect of Nitraria retusa leaf extract on the DNA damage}

Table 4 represents the impact of Nitraria retusa leaf extract on DNA damage in male mice exposed to MMC measured by comet assay. The results exhibited that treatment of male mice with MMC induced significantly $(P<0.01)$ the DNA damage in liver tissues of MMC-treated mice compared with control mice. Also, most of DNA damage in male mice treated with MMC was in class 3 in which the tail length was greater than two times the diameter of nucleus.

In contrary, MMC-treated mice supplemented with 50 and $100 \mathrm{mg} / \mathrm{kg}$ body wt of Nitraria retusa leaf extracts for 3 days showed a significant decrease $(P<0.05)$ in the DNA damage compared with the male mice treated with MMC alone but most of DNA damage in these groups was in class 3 of tail length. Moreover, MMC-treated mice administrated with 50 and $100 \mathrm{mg} / \mathrm{kg}$ body wt of Nitraria retusa leaf extracts for 1 week and 1 month showed significant decreases $(P<0.05$ and $P<0.01$, respectively) in the DNA damage compared with the male mice treated with MMC alone. Furthermore, the MMC-treated mice administrated with 50 and $100 \mathrm{mg} /$ kg body wt of Nitraria retusa leaf extracts for 1 month showed the lowest DNA damage which was relatively near to that in the control group.

\section{Effect of Nitraria retusa leaf extract on the alteration of the expression of antioxidant encoding genes}

Figures 1,2, and 3 represent the expression levels of antioxidant encoding genes in liver issues of MMC-treated mice supplemented with different doses $(50$ and $100 \mathrm{mg} / \mathrm{kg}$

Table 1 Primer used for qRT-PCR amplification

\begin{tabular}{llll}
\hline Gene & Primer sequences (5'----'3) & & References \\
\hline CAT & F-CCT TCA AGT TGG TTA ATG CAG A & R-CAA GTT TTT GAT GCC CTG GT & Kobori et al. (2015) \\
GPx & F-TTT CCC GTG CAA TCA GTT C & R-TCG GAC GTA CTT GAG GGA AT & Kobori et al. (2015) \\
GSTT1 & F-TGT GGC ATA AGG TGA TGT TC & R-GAC GCC CTTC AAA GAC TG & Badr, Saadat, and Mostafa Saadat (2016) \\
B-actin & F- GTG GGC CGC TCT AGG CAC CAA & R- CTC TTT GAT GTC ACG CAC GAT TTC & Khalil and Booles (2011) \\
\hline
\end{tabular}




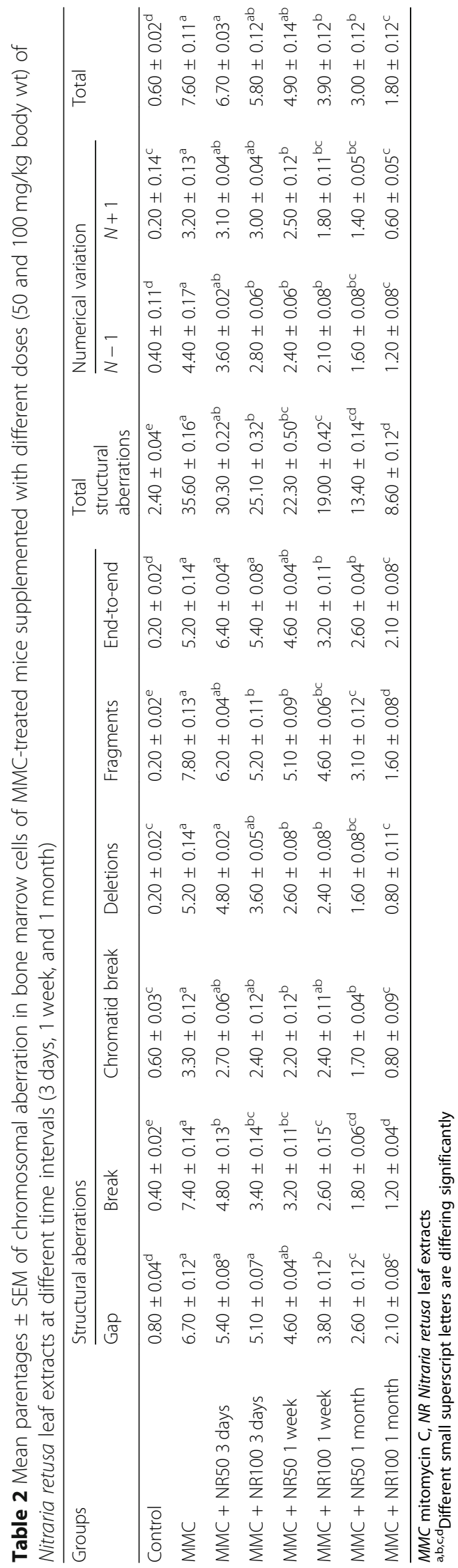


Table 3 Mean parentages of chromosomal aberration in spermatocyte cells of MMC-treated mice supplemented with different doses (50 and $100 \mathrm{mg} / \mathrm{kg}$ body wt) of Nitraria retusa leaf extracts at different time intervals (3 days, 1 week, and 1 month)

\begin{tabular}{|c|c|c|c|c|c|c|c|c|c|c|c|c|c|c|c|}
\hline \multirow[t]{3}{*}{ groups } & \multirow{3}{*}{$\begin{array}{l}\text { No. of } \\
\text { examined } \\
\text { cells }\end{array}$} & \multicolumn{8}{|c|}{ Structural aberrations } & \multirow{3}{*}{$\begin{array}{l}\text { Total } \\
\text { abr. } \\
\text { No. }\end{array}$} & \multicolumn{4}{|c|}{ Numerical variation } & \multirow{3}{*}{$\begin{array}{l}\text { Total } \\
\text { num } \\
\text { variation } \\
\text { No. }\end{array}$} \\
\hline & & \multicolumn{2}{|c|}{ Chain } & \multicolumn{2}{|c|}{ Ring } & \multicolumn{2}{|c|}{ Autosomal univalent } & \multicolumn{2}{|c|}{$x-y$ univalent } & & \multicolumn{2}{|c|}{$N-1$} & \multicolumn{2}{|c|}{$N+1$} & \\
\hline & & No. & $\%$ & No. & $\%$ & No. & $\%$ & No. & $\%$ & & No. & $\%$ & No. & $\%$ & \\
\hline Control & 250 & 2 & 0.4 & 1 & 0.2 & 0 & 0.0 & 2 & 0.4 & 5 & 2 & 0.66 & 1 & 0.33 & 3 \\
\hline MMC & 250 & 14 & 0.27 & 12 & 0.23 & 11 & 0.21 & 15 & 0.29 & 52 & 13 & 0.45 & 16 & 0.55 & 29 \\
\hline MMC + NR50 3 days & 250 & 10 & 0.24 & 11 & 0.26 & 9 & 0.21 & 12 & 0.29 & 42 & 9 & 0.41 & 13 & 0.59 & 22 \\
\hline MMC + NR100 3 days & 250 & 9 & 0.24 & 9 & 0.24 & 8 & 0.22 & 11 & 0.30 & 37 & 8 & 0.42 & 11 & 0.58 & 19 \\
\hline MMC + NR50 1 week & 250 & 8 & 0.26 & 7 & 0.23 & 7 & 0.23 & 8 & 0.27 & 30 & 6 & 0.40 & 9 & 0.60 & 15 \\
\hline MMC + NR100 1 week & 250 & 6 & 0.28 & 5 & 0.23 & 5 & 0.23 & 6 & 0.28 & 21 & 5 & 0.40 & 6 & 0.60 & 11 \\
\hline MMC + NR50 1 month & 250 & 4 & 0.25 & 3 & 0.19 & 4 & 0.25 & 5 & 0.31 & 16 & 4 & 0.57 & 3 & 0.43 & 7 \\
\hline MMC + NR100 1 month & 250 & 3 & 0.23 & 2 & 0.22 & 2 & 0.22 & 2 & 0.22 & 9 & 3 & 0.6 & 2 & 0.4 & 5 \\
\hline
\end{tabular}

MMC mitomycin C, NR Nitraria retusa leaf extracts

body wt) of Nitraria retusa leaf extracts at different time intervals ( 3 days, 1 week, and 1 month). The results showed that treatment of male mice with MMC reduced significantly $(P<0.01)$ the expression levels of CAT, GPx, and GSTT1 genes in liver tissues of MMC-treated mice compared with control mice. The expression levels of these genes had begun to increase in liver tissues of MMC-treated mice supplemented with $50 \mathrm{mg} / \mathrm{kg}$ body wt of Nitraria retusa leaf extracts for 3 days but without significant differences and with $100 \mathrm{mg} / \mathrm{kg}$ body wt with significant differences $(P<0.05)$ compared with those in male mice treated with $\mathrm{MMC}$ alone.

Furthermore, the expression levels of CAT, GPx, and GSTT1 genes in liver tissues of MMC-treated mice supplemented with 50 and $100 \mathrm{mg} / \mathrm{kg}$ body wt of Nitraria retusa leaf extracts for 1 week and 1 month increased with highly significant differences $(P<0.01$ and $P<0.001$, respectively) compared with those in male mice treated with MMC alone. Moreover, the MMC-treated mice administrated with 50 and $100 \mathrm{mg} / \mathrm{kg}$ body wt of Nitraria retusa leaf extracts for 1 month showed the highest expression levels of CAT, GPx, and GSTT1 genes which were relatively similar to those in control mice.

\section{Discussion}

The present study was conducted to investigate the effective role of Nitraria retusa leaf extracts against mitomycin $\mathrm{C}$-induced genotoxicity in male mice. The results showed that treatment of male mice with single dose of mitomycin $C$ induced high main values of chromosomal aberrations either in bone marrow cells or spermatocytes compared with the control group. Also, treatment of male mice with MMC induced significantly the DNA damage and reduced significantly the expression levels of the antioxidant-related genes encoding enzymes: CAT, GPx, and GST in liver tissues of MMC-treated mice compared with control mice.

Table 4 Rate of DNA damage in liver tissues of MMC-treated mice supplemented with different doses (50 and $100 \mathrm{mg} / \mathrm{kg}$ body wt) of Nitraria retusa leaf extracts at different time intervals (3 days, 1 week, and 1 month) using comet assay

\begin{tabular}{|c|c|c|c|c|c|c|c|}
\hline \multirow[t]{2}{*}{ Treatment } & \multicolumn{2}{|l|}{ No. of cells } & \multicolumn{4}{|c|}{ Class $^{*}$ of comet } & \multirow{2}{*}{$\begin{array}{l}\text { DNA } \\
\text { damaged } \\
\text { cells (mean } \\
\pm \text { SEM) }\end{array}$} \\
\hline & Analyzed* & $\overline{\text { Total comets }}$ & $\overline{0}$ & 1 & 2 & 3 & \\
\hline$\overline{\text { Control }}$ & 500 & 31 & 469 & 24 & 7 & 0 & $6.2 \pm 0.26^{\mathrm{e}}$ \\
\hline MMC & 500 & 137 & 363 & 29 & 47 & 61 & $27.4 \pm 0.22^{\mathrm{a}}$ \\
\hline $\mathrm{MMC}+\mathrm{NR} 503 \mathrm{~d}$ & 500 & 113 & 387 & 31 & 38 & 44 & $22.6 \pm 0.35^{b}$ \\
\hline $\mathrm{MMC}+\mathrm{NR} 1003$ days & 500 & 104 & 396 & 28 & 35 & 41 & $20.8 \pm 0.42^{\mathrm{bc}}$ \\
\hline $\mathrm{MMC}+\mathrm{NR50} 1 \mathrm{~W}$ & 500 & 91 & 409 & 23 & 32 & 36 & $18.2 \pm 0.28^{c}$ \\
\hline MMC + NR100 1 week & 500 & 74 & 426 & 24 & 29 & 21 & $14.8 \pm 0.45^{\mathrm{cd}}$ \\
\hline MMC + NR50 1 month & 500 & 51 & 449 & 22 & 17 & 12 & $10.2 \pm 0.33^{d}$ \\
\hline MMC + NR100 1 month & 500 & 42 & 458 & 19 & 15 & 8 & $8.4 \pm 0.25^{\text {de }}$ \\
\hline
\end{tabular}

${ }^{¥}$ Class $0=$ no tail; 1 = tail length $<$ diameter of nucleus; $2=$ tail length between $1 \times$ and $2 \times$ the diameter of nucleus; and $3=$ tail length $>2 \times$ the diameter of nucleus. *No of cells analyzed were 100 per an animal

$a, b, c, d, e$ Different small superscript letters are differing significantly. 


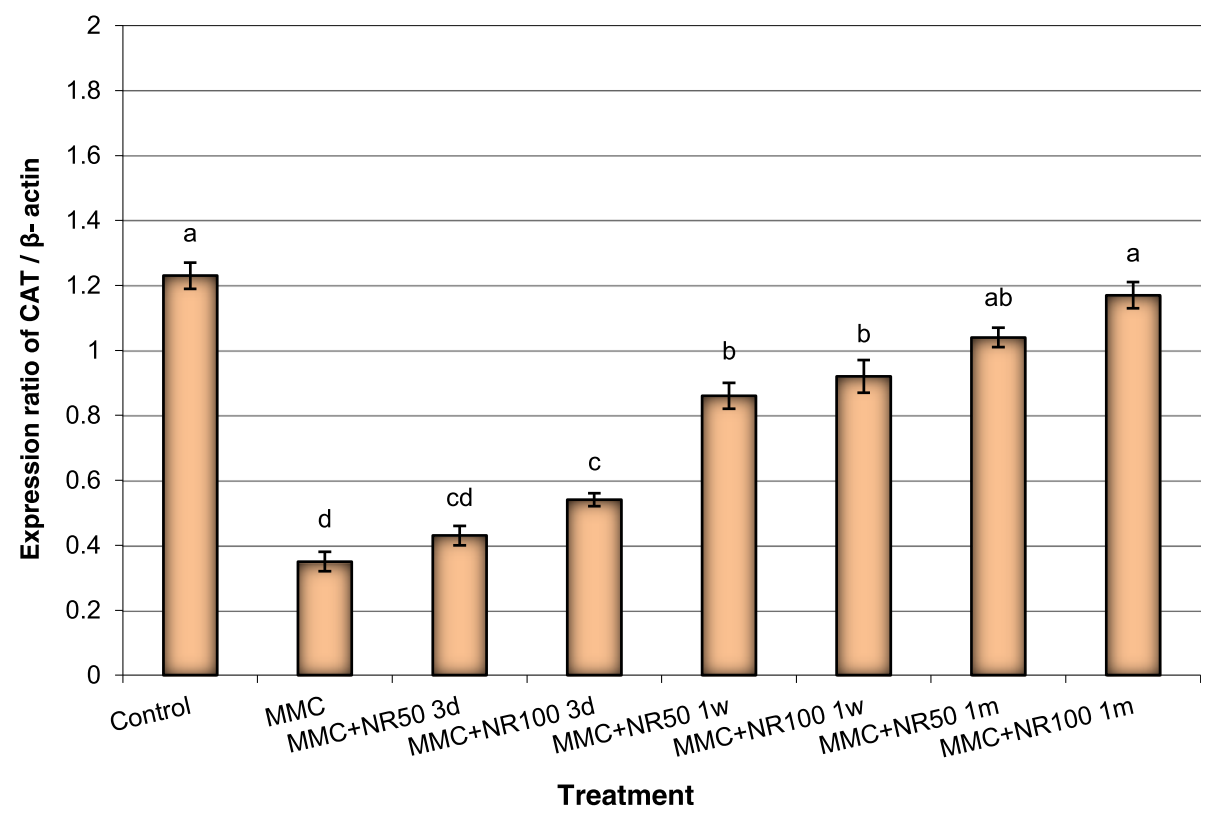

Fig. 1 Expression alteration of CAT gene in liver tissues collected from MMC-treated mice supplemented with different doses $(50$ and $100 \mathrm{mg} / \mathrm{kg}$ body wt) of Nitraria retusa leaf extracts at different time intervals (3 days, 1 week, and 1 month). Data are presented as mean \pm SEM. ${ }^{a, b, c, d}$ Mean values within tissue with unlike superscript letters were significantly different $\left({ }^{a} P<0.01,{ }^{b}, c, d p<0.05\right)$

In the same line with our findings, Shimada et al. (2015) reported that treatment of young adult rats with MMC increased the frequency of micronucleus formation. In addition, they found that the genotoxic effect of MMC was showed in dose-dependent manner and duration of treatments ( 2 and 4 weeks). In the present study, our findings were dependent on only single treatment of MMC and different time intervals of the supplementation with Nitraria retusa leaf extracts. Moreover, Rjiba-Touati et al. (2013) found that treatment of bone marrow cells of rats

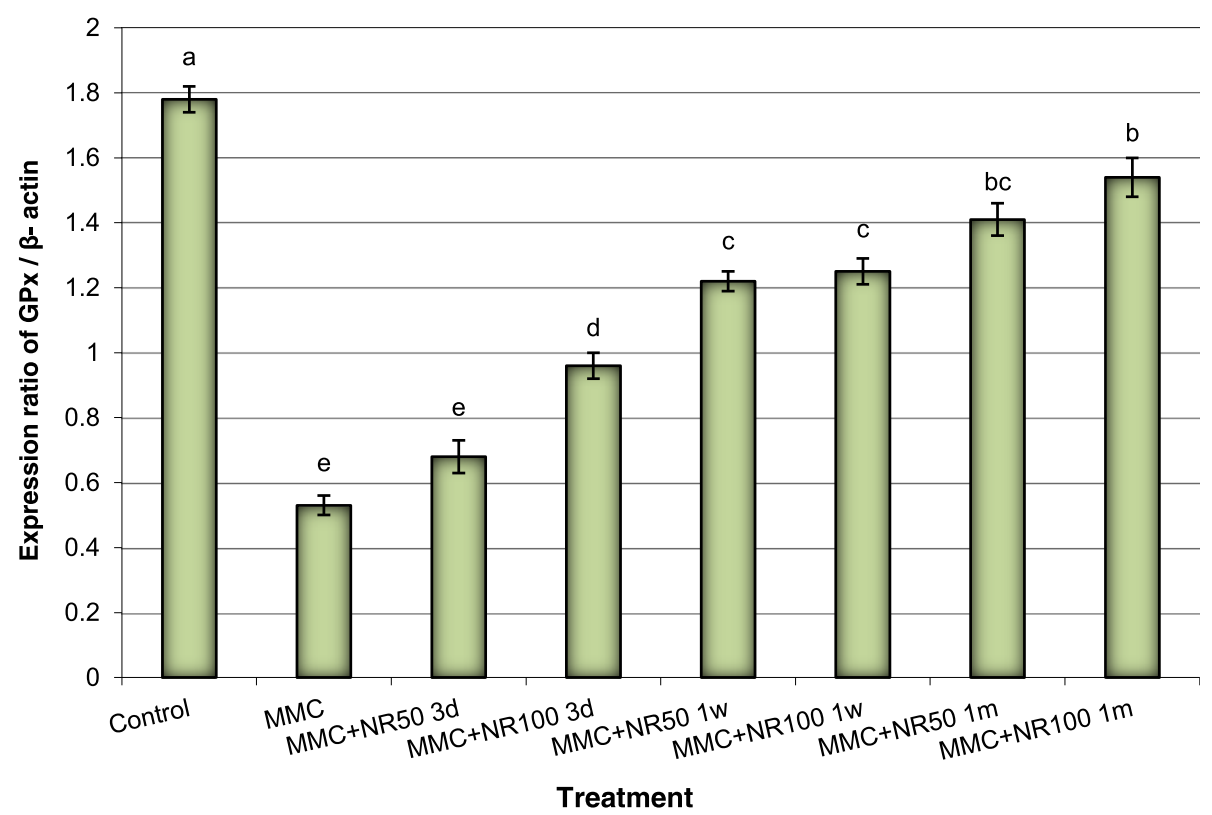

Fig. 2 Expression alteration of GPx gene in liver tissues collected from MMC-treated mice supplemented with different doses (50 and $100 \mathrm{mg} / \mathrm{kg}$ body wt) of Nitraria retusa leaf extracts at different time intervals (3 days, 1 week, and 1 month). Data are presented as mean \pm SEM. ${ }^{a, b, c, d}$ Mean values within tissue with unlike superscript letters were significantly different $\left({ }^{\mathrm{a}} P<0.01,{ }^{\mathrm{b}, \mathrm{c}, \mathrm{d}} P<0.05\right)$ 


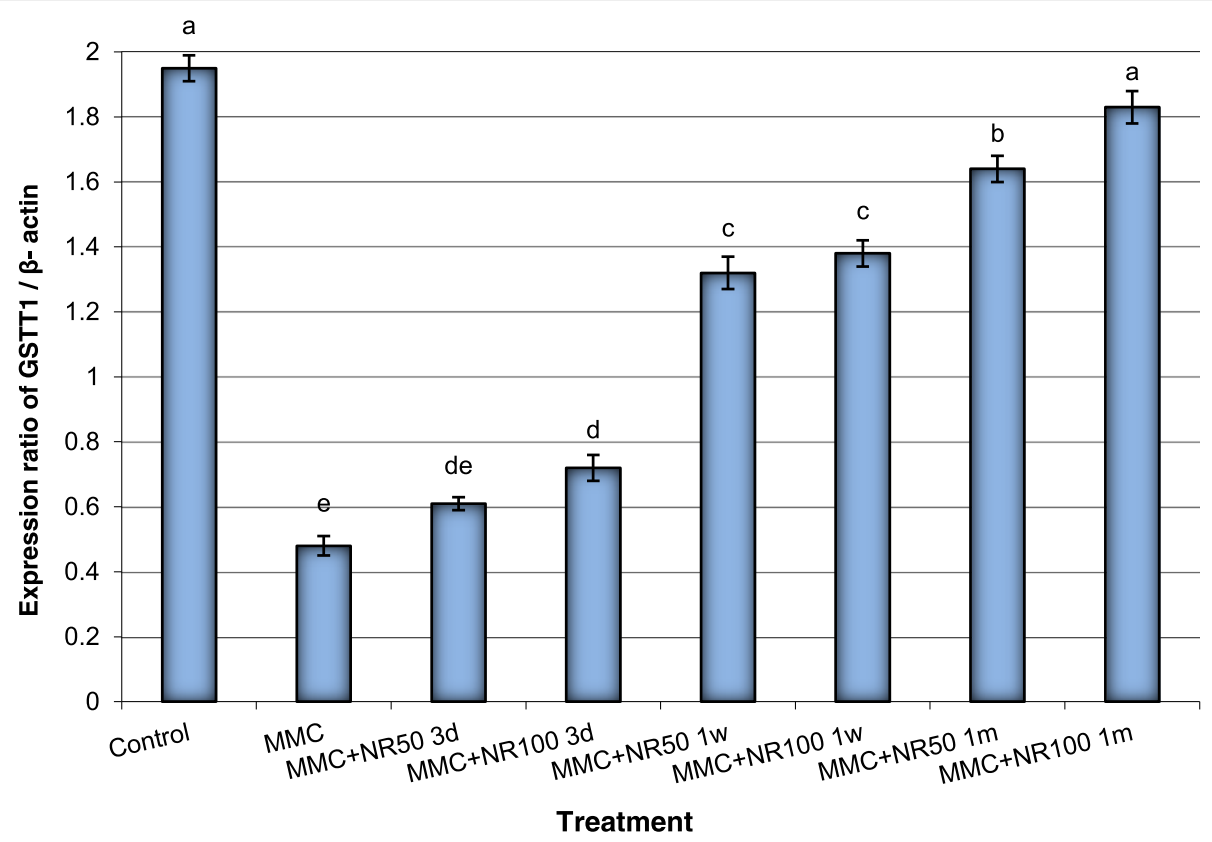

Fig. 3 Expression alteration of GSTT1 gene in liver tissues collected from MMC-treated mice supplemented with different doses (50 and $100 \mathrm{mg} /$ $\mathrm{kg}$ body wt) of Nitraria retusa leaf extracts at different time intervals (3 days, 1 week, and 1 month). Data are presented as mean \pm SEM. ${ }^{a, b, c, d}$ Mean values within tissue with unlike superscript letters were significantly different $\left({ }^{a} P<0.01,{ }^{b}, c, d p<0.05\right)$

with MMC induced chromosome abnormalities, micronucleus formation, and DNA fragmentation.

MMC has been extensively used for genotoxicity studies as positive mutagenic agent. Therefore, it is considered as reference genotoxic agent for genetic toxicity study as mentioned by Economic-Cooperation and Development (Jena \& Bhunya, 1995; OECD, 1997). Several studies have reported that MMC is metabolizing in the cells and generating ROS and creating different types of DNA adducts as well as causing gene expression alterations (Abbas et al., 2002; Korkina et al., 2000; Pawar, Tripathi, Ramarao, \& Jena, 2007). Moreover, it has been observed that MMC is altering the expression of p53 gene and inducing the apoptosis in the death pathways of the mammalian cells (Pawar et al., 2007).

On the other hand, our results showed that MMC-treated mice administrated with 50 and $100 \mathrm{mg} / \mathrm{kg}$ body wt of Nitraria retusa leaf extracts for 1 month showed significant decreases in the chromosomal aberrations and DNA damage as well as increase the expression of the antioxidant-related genes more than 1 week and 3 days' treatments.

For our best of knowledge, there are no published data regarding the effect of Nitraria retusa extract on the anti-genotoxicity in in vivo mammalian cells. However, Chaâbane et al. (2017) reported that $N$. retusa fruit extract exhibited a highly protective action against toxic effect of penconazole which induce kidney injury. They suggested that the protective action of $N$. retusa fruit extract could result from its content of the phenolic compounds. Boubaker et al. (2018) indicated that treatment of tumor-induced mice with leaf extracts of $N$. retusa showed anti-tumor activity which was attributed to its most important components in the $N$. retusa, namely, palmitic acid and $\beta$-sitosterols (Boubaker, Chaabane, et al., 2015a; Boubaker, Mokdad Bzeouich, et al., 2015b).

Several reports have indicated that isolated polyphenolic components from plant materials have antitumor and anti-genotoxic properties (Philion et al., 2017; Surh \& Ferguson, 2003). They showed that the polyphenolic components scavenge free radicals from the cells and consequently protect the cellular systems from oxidative damage inducing DNA fragmentation and tumor induction. Additionally, extracted natural products are containing numerous bioactive components which probably are targeting many of pathways associated with cancer to induce apoptosis and consequently death of the tumor cells (Philion et al., 2017). It has been found that Nitraria retusa extracts have been recorded for anti-mutagenic and anti-oxidant activities as well as enhancing apoptosis which attributed to its contents of polyphenolic components (Boubaker et al., 2012a; Skandrani, Pinon, Simon, Ghedira, \& Chekir-Ghedira, 2010). Moreover, Boubaker, Ben Sghaier, et al., 2012b reported that the protective action of Nitraria retusa extracts are attributed to its contents of isorhamnetin 3-o-robinobioside which is responsible for antioxidant and antigenotoxic activities when investigated its role on leukemia cell line. 
The present study found that Nitraria retusa leaf extract increased the expression levels of antioxidant enzymes genes (CAT, GPx, and GSTT1) which could be associated with inhibition of DNA damage and decrease the frequency of chromosomal aberrations. Ratliff, Abdulmahdi, Pawar, and Wolin (2016) reported that the imbalance between the antioxidant capacity and generation of ROS is increasing the oxidative damage and affecting the mechanism of the immune system. Thus, the present results suggested that the protective effects of Nitraria retusa leaf extract could be attributed to promoting the expression of CAT, GPx, and GSTT1 and decline in the ROS generation in the mice cells.

\section{Conclusion}

The present work observed that supplementation of male mice with Nitraria retusa leaf extract enhanced the protective action through decreasing the chromosome abnormalities and DNA damage as well as inhibiting the gene expression alterations induced by MMC in hepatic cells of male mice. The action mechanism of the Nitraria retusa leaf extract in protecting the hepatic cells could result to the presence of isorhamnetin 3-o-robinobioside, palmitic acid, and $\beta$-sitosterols in its extract which are known for their anti-tumor and anti-mutagenic activities.

\section{Abbreviations}

CAT: Catalase; GPx: Glutathione peroxidase; GSTT1: Glutathione S-transferase (GST) theta 1; MMC: Mitomycin C; NR: Nitraria retusa leaf extracts;

ROS: Reactive oxygen species

\section{Acknowledgements}

The genetic and biochemical analyses were carried out in the National Research Centre, Egypt. The authors thank everyone who assisted in this study.

\section{Funding}

This study was funded from the National Research Centre, as In-House project Number: 10070212, entitled: Evaluation of potential Antimutagenic and Anti-carcinogenic Effects of Some Medicinal Plants Growing Naturally at Egypt by Some Biological Systems. It awarded to Dr. Ekram S. Ahmed, as she was the Principle Investigator.

\section{Availability of data and materials}

The datasets generated and analyzed during the current study are available from the corresponding author on reasonable request.

\section{Authors' contributions}

All authors suggested the study, participated in its design and coordination, interpreted the results, and approved the final manuscript.

\section{Ethics approval and consent to participate}

All applicable international, national, and institutional guidelines for the care and use of animals were followed. All procedures performed in this study involving the animal treatments were in accordance with the ethical standards of the Egyptian Code of Conduct for Scientific Practice, National Research Centre, Egypt, where the study was conducted and who granted the ethical approval for the conduct of the research.

\section{Consent for publication}

Not applicable.

\section{Competing interests}

The authors declare that they have no competing interests.

\section{Publisher's Note}

Springer Nature remains neutral with regard to jurisdictional claims in published maps and institutional affiliations.

Received: 25 October 2018 Accepted: 1 April 2019

Published online: 29 April 2019

\section{References}

Abbas, T., Olivier, M., Lopez, J., Houser, S., Xiao, G., Kumar, G. S., Bargonetti, J. (2002). Differential activation of $p 53$ by the various adducts of mitomycin $C$. The Journal of Biological Chemistry, 277, 40513-40519.

Adler, I. D. (1974). Comparative cytogenetic study after treatment of mouse spermatogonia with Mitomycin C. Mutation Research, 23, 369-379.

Badr, A. A., Saadat, I., \& Mostafa Saadat, M. (2016). Study of liver function and expression of some detoxification genes in the male rats exposed to methyl-tertiary butyl ether. The Egyptian Journal of Medical Human Genetics, 17, 325-329.

Barnes, R. P., Fouquerel, E., \& Opresko, P. L. (2018). The impact of oxidative DNA damage and stress on telomere homeostasis. Mechanisms of Ageing and Development, 177, 37-45.

Blasiak, J., Arabski, M., Krupa, R., Wozniak, K., Zadrozny, M., Kasznikcki, J., Drzewoski, J. (2004). DNA damage and repair in type 2 diabetes mellitus. Mutation Research/Fundamental and Molecular Mechanisms of Mutagenesis, 554(1-2), 297-304.

Boamah, E. K., White, D. E., Talbott, K. E., Arva, N. C., Berman, D., Tomasz, M., \& Bargonetti, J. (2007). Mitomycin-DNA adducts induce p53-dependent and p53-independent cell death pathways. ACS Chemical Biology, 2, 399-407.

Boubaker, J., Ben Sghaier, M., Skandrani, I., Ghedira, K., \& Chekir-Ghedira, L. (2012b). Isorhamnetin 3-O-robinobioside from Nitraria retusa leaves enhance antioxidant and antigenotoxic activity in human chronic myelogenous leukemia cell line K562. BMC Complementary and Alternative Medicine, 12, 135.

Boubaker, J., Ben Toumia, I., Sassi, A., Bzouich-Mokded, I., Ghoul Mazgar, S., Sioud, F., ... Chekir-Ghedira, L. (2018). Antitumoral potency by immunomodulation of chloroform extract from leaves of Nitraria retusa, Tunisian medicinal plant, via its major compounds $\beta$-sitosterol and palmitic acid in BALB/C mice bearing induced tumor. Nutrition and Cancer, 70(4), 650-662.

Boubaker, J., Bhouri, W., Ben Sghaier, M., Bouhlel, I., Kriffi, M., Skandrani, I., et al. (2012a). Flavonoids products from Nitraria retusa leaves promote lymphoblastoid cells apoptosis. Nutrition and Cancer, 64(7), 1095-1102.

Boubaker, J., Chaabane, F., Bedoui, A., Aloui, R., Ahmed, B. B., Ghedira, K, \& Chekir-Ghedira, L. (2015a). Antitumoral potency of methanolic extract from Nitraria retusa leaves via its immunomodulatory effect. Cancer Cell International, 15, 82.

Boubaker, J., Mokdad Bzeouich, I., Nasr, N., Ben Ghozlen, H., Mustapha, N. Ghedira, K., \& Chekir-Ghedira, L. (2015b). Phytochemical capacity of Nitraria retusa leaves extracts inhibiting growth of melanoma cells and enhancing melanogenesis of B16F10 melanoma. BMC Complementary and Alternative Medicine, 15, 300 .

Boubaker, J., Skandrani, I., Bouhlel, I., et al. (2010). Mutagenic, antimutagenic and antioxidant potency of leaf extracts from Nitraria retusa. Food and Chemical Toxicology, 48(8-9), 2283-2290.

Chaâbane, M., Koubaa, M., Soudani, N., Elwej, A., Grati, M., Jamoussi, K., Zeghal, N. (2017). Nitraria retusa fruit prevents penconazole-induced kidney injury in adult rats through modulation of oxidative stress and histopathological changes. Pharmaceutical Biology, 55(1), 1061-1073.

Corona, G., Coman, M. M., Guo, Y., Hotchkiss, S., Gill, C., Yaqoob, P., Rowland, I. (2017). Effect of simulated gastrointestinal digestion and fermentation on polyphenolic content and bioactivity of brown seaweed phlorotannin-rich extracts. Molecular Nutrition \& Food Research, 61, 11.

De Flora, S., \& Ferguson, L. R. (2005). Overview of mechanisms of cancer chemopreventive agents. Mutation Research, 591, 8-15.

Doleski, P. H., Ten Caten, M. V., Passos, D. F., Castilhos, L. G., Leal, D. B. R., Machado, V. S., da Silva, A. S. (2017). Toxoplasmosis treatment with diphenyl diselenide in infected mice modulates the activity of purinergic enzymes and reduces inflammation in spleen. Experimental Parasitology, 181, 7-13.

Dong, X., Tong, F., Qian, C., Zhang, R., Dong, J., Wu, G., \& Hu, Y. (2015). NEMO modulates radiation-induced endothelial senescence of human umbilical veins through NF-KB signal pathway. Radiation Research, 183(1), 82-93. 
El Hawary, S. S., Saad, S., El Halawany, A. M., Ali, Z. Y., \& El Bishbishy, M. (2016). Phenolic content and anti-hyperglycemic activity of pecan cultivars from Egypt. Pharmaceutical Biology, 54(5), 788-798.

El-Alali, A., AlZoui, A., Gharaibeh, M., Tawaha, K., \& Alali, F. Q. (2012). Phytochemical and biological investigation of Nitraria retusa asch. Jordan Journal of Pharmaceutical Sciences, 5, 2.

Elmegeed, G. A., Khalil, W. K. B., Abdel Raouf, A., \& Abdelhalim, M. M. (2008). Synthesis and in vivo anti-mutagenic activity of novel melatonin derivatives. European Journal of Medicinal Chemistry, 43, 763-770.

Evans, E. P., Breckon, G., \& Ford, C. E. (1964). An air-dried method for meiotic preparations from mammalian testes. Cytogenetics, 3, 289-294.

Gederaas, O. A., Søgaard, C. D., Viset, T., Bachke, S., Bruheim, P., Arum, C. J., \& Otterlei, M. (2014). Increased anticancer efficacy of intravesical mitomycin C therapy when combined with a PCNA targeting peptide. Translational Oncology, 7(6), 812-823.

Jena, G. B., \& Bhunya, S. P. (1995). Use of chick, Gallus domesticus, as an in vivo model for the study of chromosome aberration: A study with mitomycin C and probable location of a "hot spot". Mutation Research, 334, 167-174.

Kalai, F. Z., Han, J., Ksouri, R., El Omri, A., Abdelly, C., \& Isoda, H. (2013). Antiobesity effects of an edible halophyte Nitraria retusa Forssk in 3T3-L1 preadipocyte differentiation and in C57B6J/L mice fed a high fat diet-induced obesity. Evidence-based Complementary and Alternative Medicine. https://doi.org/10. 1155/2013/368658.

Kaur, P., Kaur, V., Kumar, M., \& Kaur, S. (2014). Suppression of SOS response in E. coli PQ 37, antioxidant potential and antiproliferative action of methanolic extract of Pteris vittata L. on human MCF-7 breast cancer cells. Food and Chemical Toxicology, 74, 326-333.

Khalil, W. K. B., \& Booles, H. F. (2011). Protective role of selenium against overexpression of cancer-related apoptotic genes induced by o-cresol in rats. Arhiv za Higijenu Rada i Toksikologiju, 62, 121-129.

Khalil, W. K. B., Booles, H. F., Hafiz, N. A., \& El-Bassyouni, G. E. (2018). Ameliorative effects of Brachidontes variabilis calcium carbonate against bone loss in ovariectomized rats. International Journal of Pharmacology, 14, 477-487.

Kobori, M., Takahashi, Y., Akimoto, Y., Sakurai, M., Matsunaga, I., Nishimuro, H., Ohnishi-Kameyama, M. (2015). Chronic high intake of quercetin reduces oxidative stress and induces expression of the antioxidant enzymes in the liver and visceral adipose tissues in mice. Journal of Functional Foods, 15, 551-560.

Korkina, L. G., Deeva, I. B., De Biase, A., laccarino, M., Oral, R., Warnau, M., \& Pagano, G. (2000). Redox-dependent toxicity of diepoxybutane and mitomycin C in sea urchin embryogenesis. Carcinogenesis, 21, 213-220.

Linjawi, S. A. A., Khalil, W. K. B., Hassanane, M. M., \& Ahmed, E. S. (2015). Evaluation of the protective effect of Nigella sativa extract and its primary active component thymoquinone against DMBA-induced breast cancer in female rats. Archives of Medical Science, 11(1), 220-229.

Mao, Y., Varoglu, M., \& Sherman, D. H. (1999). Molecular characterization and analysis of the biosynthetic gene cluster for the antitumor antibiotic mitomycin C from Streptomyces lavendulae NRRL 2564. Chemistry \& Biology, $6,251-263$

OECD (1997). Test guideline 474: Mammalian erythrocyte micronucleus test. In OECD Guidelines for Testing of Chemicals.

Pawar, A. A., Tripathi, D. N., Ramarao, P., \& Jena, G. (2007). Protective effects of American ginseng (Panax quinquefolium) against mitomycin C-induced micronuclei in mice. Phytotherapy Research, 21, 1221-1227.

Pawar, A. A., Vikram, A., Tripathi, D. N., Padmanabhan, S., Ramarao, P., \& Jena, G. (2009). Modulation of mitomycin C-induced genotoxicity by acetyl- and thioanalogues of salicylic acid. In Vivo, 23(2), 303-307.

Philion, C., Ma, D., Ruvinov, I., Mansour, F., Pignanelli, C., Noel, M., Pandey, S. (2017). Cymbopogon citratus and Camellia sinensis extracts selectively induce apoptosis in cancer cells and reduce growth of lymphoma xenografts in vivo. Oncotarget, 8(67), 110756-110773.

Ratliff, B. B., Abdulmahdi, W., Pawar, R., \& Wolin, M. S. (2016). Oxidant mechanisms in renal injury and disease. Antioxidants \& Redox Signaling, 25(3), 119-146.

Rjiba-Touati, K., Ayed-Boussema, I., Guedri, Y., Achour, A., Bacha, H., \& Abid, S. (2013). Role of recombinant human erythropoietin in mitomycin Cinduced genotoxicity: analysis of DNA fragmentation, chromosome aberrations and micronuclei in rat bone-marrow cells. Mutation Research, 753(1), 48-53.

Rjiba-Touati, K., Ayed-Boussema, I., Guedri, Y., Achour, A., Bacha, H., \& Abid-Essefi, S. (2016). Effect of recombinant human erythropoietin on mitomycin Cinduced oxidative stress and genotoxicity in rat kidney and heart tissues. Human \& Experimental Toxicology, 35(1), 53-62.
Salem, N. A., Wahba, M. A., Eisa, W. H., El-Shamarka, M., \& Khalil, W. (2017). Silver oxide nanoparticles alleviate indomethacin-induced gastric injury: A novel antiulcer agent. Inflammopharmacology. https://doi.org/10.1007/ s10787-017-0424-2.

SAS Institute (1982). SAS user's guide: Statistics. 1982 edition. Cary: SAS Institute Inc. Sayed, R. H., Khalil, W. K. B., Salem, H. A., Kenawy, S. A., \& El-Sayeh, B. M. (2014). Sulforaphane increases the survival rate in rats with fulminant hepatic failure induced by D-galactosamine and lipopolysaccharide. Nutrition Research, 34, 982-989.

Shimada, K., Yamamoto, M., Takashima, M., Wako, Y., Kawasako, K., Aoki, Y., Wakata, A. (2015). Repeated-dose liver micronucleus assay of mitomycin C in young adult rats. Mutation Research, Genetic Toxicology and Environmental Mutagenesis, 780-781, 85-89.

Skandrani, I., Pinon, A., Simon, A., Ghedira, K., \& Chekir-Ghedira, L. (2010). Chloroform extract from Moricandia arvensis inhibits growth of B16-F0 melanoma cells and promotes differentiation in vitro. Cell Proliferation, 43, 471-479.

Surh, Y. J., \& Ferguson, L. R. (2003). Dietary and medicinal antimutagens and anticarcinogens: Molecular mechanisms and chemopreventive potential highlights of a symposium. Mutation Research, 523, 1-8.

van Valenberg, F. J. P., Strauss-Ayali, D., Agmon-Gerstein, Y., Friedman, A., Arentsen, H. C., Schaafsma, H. E., Oosterwijk, E. (2018). Assessment of the efficacy of repeated instillations of mitomycin $C$ mixed with a thermosensitive hydrogel in an orthotopic rat bladder cancer model. Therapeutic Advances in Urology, 10(7), 213-221.

Verma, S., \& Gupta, M. L. (2015). Radiation-induced hematopoietic myelosuppression and genotoxicity get significantly countered by active principles of Podophyllum hexandrum: A study in strain ' $A$ ' mice. International Journal of Radiation Biology, 91(9), 757-770.

Williams, D. E., Dashwood, R. H., Hendricks, J. D., \& Bailey, G. S. (1989). Antiarcinogens and tumor promoters in foods. In S. L. Tayor, \& R. A. Scanlan (Eds.), Food toxicology - a perspective on relative risks, (p. 101). New York: Marcel Dekker.

Wolfe, L. K., \& Liu, R. H. (2007). Cellular antioxidant activity (CAA) assay for assessing antioxidants, foods and dietary supplements. Journal of Agricultural and Food Chemistry, 5, 8896-8907.

Zhang, H. H., Huang, B., Cao, Y. H., Li, Q., \& Xu, H. F. (2017). Role of 5-Aza-CdR in mitomycin-C chemosensitivity of T24 bladder cancer cells. Oncology Letters, 14(5), 5652-5656.

\section{Submit your manuscript to a SpringerOpen ${ }^{\circ}$ journal and benefit from:}

- Convenient online submission

- Rigorous peer review

- Open access: articles freely available online

High visibility within the field

- Retaining the copyright to your article

Submit your next manuscript at $\boldsymbol{\nabla}$ springeropen.com 